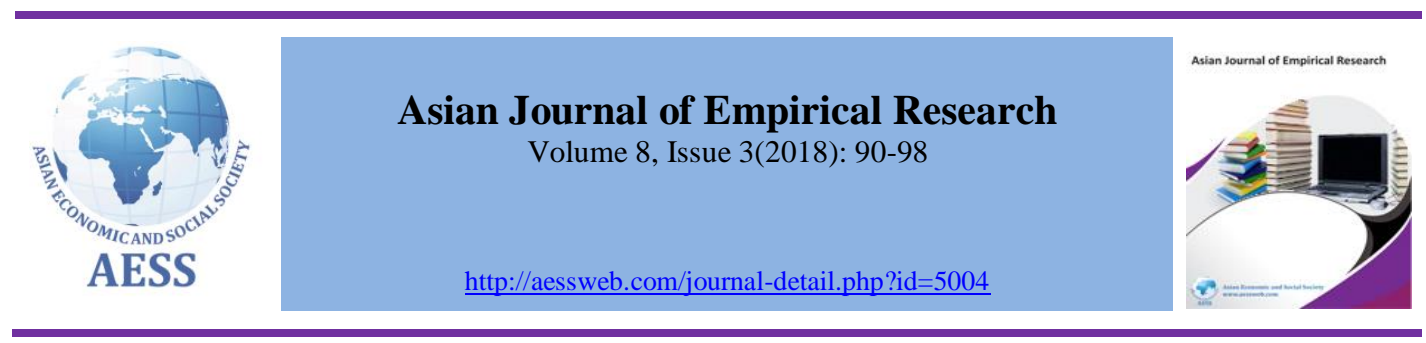

\title{
Economic unions and the gravity model: evidence from Eurasian economic union
}

\section{Robert Tumanyan}

School of Economics and Trade, Hunan University, Yuelushan, Changsha, Hunan Province, 410079, People's Republic of China

\robert92tum@gmail.com

ARTICLE HISTORY:

Received: 14-Jan-2018

Accepted: 26-Feb-2018

Online available: $12-$ Mar-

2018

\section{Keywords:}

Trade blocks, Gravity model, Intra-block trade, Economic Unions, EEU

\begin{abstract}
The purpose of this study is to analyze trade creation and trade diversion effects in the Eurasian Economic Union (EEU), which is an evolution of regional trade agreements. The research will analyze intra-block trade flows and test trade creation and diversion in EEU determined by customs union agreements. Gravity model has been applied to annual bilateral export flows for EEU countries paired with a sample of 58 partner countries in the period of 2005-2016, using augmented gravity model with panel year fixed effect, this paper analyzes trade creation and diversion effects of EEU in general. The results are similar to other identical studies and suggest that EEU is mostly trade-diverting with a minor effect of trade creation.
\end{abstract}

\section{Contribution/ Originality}

This study uses augmented gravity model of trade to analyze trade effects of Eurasian Economic Union. The article uses updates macroeconomic data and trade statistics, providing robust empirical findings. The results show major trade-diverting effects in Eurasian economic union, hence it suggests ineffective trade policy implications in the trade-block.

DOI: 10.18488/journal.1007/2018.8.3/1007.3.90.98 ISSN (P): 2306-983X, ISSN (E): 2224-4425

How to cite: Robert Tumanyan (2018). Economic unions and the gravity model: evidence from Eurasian economic union. Asian Journal of Empirical Research, 8(3), 90-98.

(C) 2018 Asian Economic and Social Society. All rights reserved 


\section{INTRODUCTION}

Regional trade agreements (RTA) rise in numbers and popularity from early 1990 and up to 2016, there are over 300 agreements reported in the World Trade Organization (WTO), alongside with different economic unions and their developments, regional trade agreements represent an important vector of international trade development.

Theoretical background on RTAs and economic unions has always been among heavily discussed topics in economics. RTA can promote the trade among member states, but on expanse on trade among non-members. Therefore, the benefits and costs joining a RTA rely on structural costs of members. The expanded theory of economic unions and RTA was Mundell in early 1960 as summaries of optimal currency area, OCA theory. Viner (1950) suggested that the trade effects applied by trading agreements are summarized, in ways called trade creation and trade diversion. Trade creation is the substitution of trade flows generated by regional trade agreement among member states, therefore it is beneficial to the member countries and the world as a whole. On the other hand, trade diversion underlines trade flows and trade directions outside of the area on the cost of lower cost from outside the area. Various researches have studied whether regional trade blocs are positive for welfare creation and economic integration among partners. Generally, the argument is that trade creation and diversion are important in understanding on RTA and unions formation, hence the welfare effects of RTA formation and the size of trade creation and diversion is the main issue to investigate. In this study, the effect of trade creation and diversion is analyzed in EEU using gravity model of trade Appling set of dummy variables typical for augmented gravity model and essential in EEU such as common border, and geo distance.

Figure 1 presents RTAs among members and EEU creation, with its historical background. ${ }^{1}$ Eurasian Economic Union (EEU) is a union of countries located in the former Soviet Union. On May 29, 2014, in Astana, the original treaty on the formation of EEU was signed between Belarus, Kazakhstan, and Russia original members of ECU that started its operations on January 1, 2015. Initially, the EEU consisted of Belarus, Kazakhstan, and Russia on platform of Eurasian customs union. Armenia and the Kyrgyz Republic joined on January 2, 2015, and August 12, 2015, respectively. The EEU represents an integrated single market of 182.7 million people and a gross domestic product (GDP) of over \$2.2 trillion US estimated in 2014.

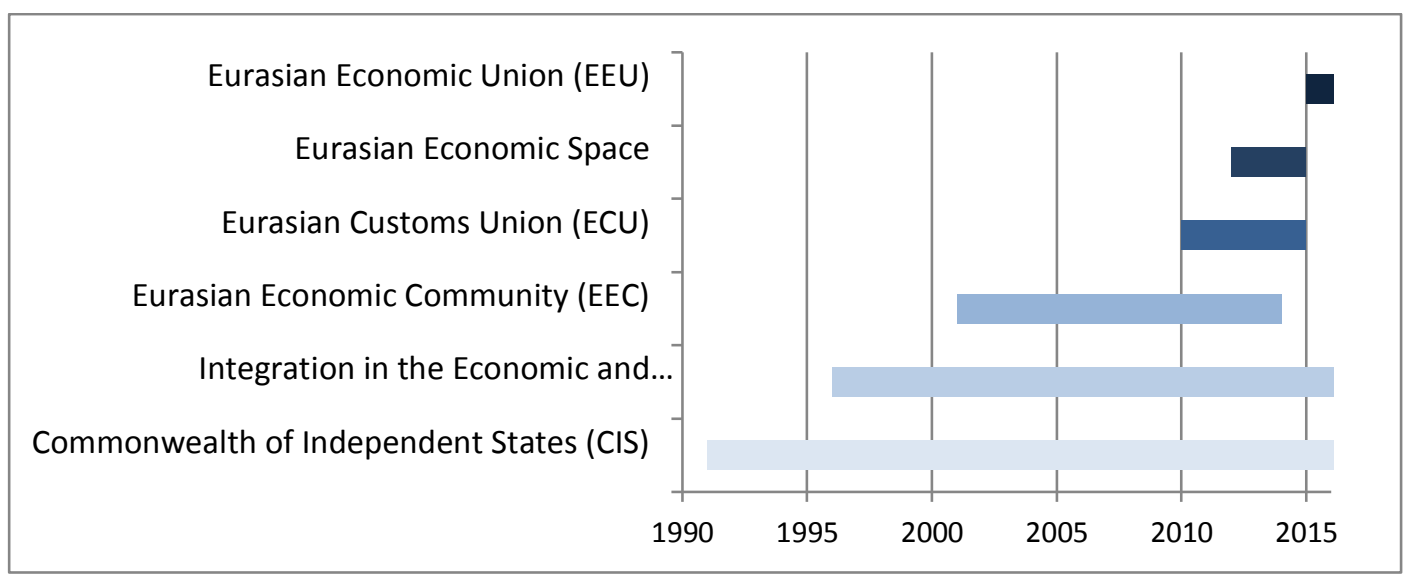

Figure 1: Evolution of EEU

Source: World Trade Organization, 2016

${ }^{1}$ RTA agreements starts with Eurasian custom union creation 
Intra-trade volume between the block is lower compared to other unions such as EU, however with introduction of single market, and common tariffs. Started from 2015 the volume of trade tends to increase. This study's objective is to analyze the effect of trade creation in EEU, for whole union in general providing empirical analyses intra-union trade creation and net trade creation for the union, which is an estimator for welfare effect analyses. The gravity model is used to estimate impacts of RTA- association with union, on the trade creation and trade diversion. The paper is organized as following sections following provide literature review on previous studies, data and methodology, empirical results and concussions respectably.

\section{LITERATURE REVIEW}

This section provides a survey over previous studies regarding gravity model, and gravity model applications on regional trade agreements and trade blocks estimations, such as the effects on trade flows in economic unions. Further various studies applied various approaches are studied here including (DeRosa, 1999; Scollay and Gilbert, 2000; Robinson and Thierfelder, 2002; Lloyd and Maclaren, 2004; Ekanayake et al., 2010). During past recent years gravity model raised in its popularity due to increase of various economic unions and regional trade agreements. First all gravity model was applied to estimate trade flows in 1960s. The model was first used by (Tinbergen, 1963) later in their research Tinbergen (1962) (Linnemann, 1966) define general specifications for gravity model of trade, alongside gravity model of trade other gravity models start to develop and gain popularity: such as models of remittances, migration and FDI. Model applications to RTAs started with Aitken (1973), Bergstrand (1985) and Deardorff (1997) developed partial theoretical fundaments close to modern days economic theory development, however due to lack of theoretical knowledge gravity models are criticized, however in respect with interest in regional trade agreements gravity model become relevant.

In first gravity model was applied to international trade by Tinbergen (1962) and Pöyhönen (1963) authors developed the model to determine international trade flows using date of 42 counties, also together with standard variables, Tinbergen included dummy variables for trade agreements, common border, colony, etc. the model. Helpman and Krugman (1985) developed a model that successfully incorporates monopolistic competition of the increasing returns theory into a Heckscher-Ohlin framework, empirical analyses explaining bilateral trade flows. Koo and Karemera (1991) and Carrillo and $\mathrm{Li}$ (2002) include per capita income variables to express the level of economic development. Augmented gravity model includes population variables and dummy variables to control for cultural similarity among trade partners, such as colonial past, language, culture groups etc. Modern Literature finds that historical links are important determinants of international trade flows. Distance was introduced by developments of augmented models. Anderson (2011) provided wide range of Gravity model implications and augmented models using various control variables.

World Trade statistics reports indicate high magnitude and volume of bilateral trade in different regional groupings such the European Union, Asia-Pacific and North America. Krugman (1980) suggests that that those regions are naturally attractive welfare groups where partners have proximate and short on distance, hence it droves to conclusion that continental regional trade agreements are trade creating due to no distance or short distance between members or sharing common borders. Frankel et al., (1995) using gravity model on south East Asian and East Asian economies discover potential trade creation in the regions, but argued that the distance and common border remains most impactful variable in trade flows determinations. Recent developments Ravishankar and Stack (2014) presented Gravity model for EU counties predicting potential trade flows for Eastern European counties. Trade relationship and economic integration was summarized by Vinokurov (2017). Russell (2017) presented issues in EEU and its trade statistics. Recent studies dedicated to EEU and its trade relationships, underline trade diverting effects of the union mostly explained by relatively small volume of intra-block trade and tariff policies in the union. 
Gravity models in EEU focuses on factors regarding regional trade agreements among member states, since EEU member share lot of common background, such as past Soviet Union states. Existing literature does not include gravity model analyses, however various authors discus possibility and prospective of EEU.

\section{DATA AND METHODOLOGY}

In this paper, an expanded gravity model is used in order to analyze trade directions and impacts in Eurasian Economic Union (EEU). First Gravity models of trade were developed and introduced to fundamental economic theory in late 60s. A study by Tinbergen (1962) applied a gravity model to analyze the variables describing trade flows between two countries. Gravity models have been adjusted different set of variables explaining factors that could either promote or reduce trade. This article follows various authors and specifies a gravity model which examines international trade in Eurasian economic union determined by control variables such as relationship between two member countries in the union. Meanwhile there are numbers of different studies on standard gravity model theory this Article focuses on empirical application of an adjusted model on a data sample representing major international trade flows in a newly formed regional trade agreement and economic union, therefore the theoretical fundaments of standard gravity models are not discussed in this article. Following Ekanayake et al. (2010) gravity model is presented as following equations equation (1) is gravity model without fixed effects and equation (2) is gravity model with year fixed effect.

$$
\begin{aligned}
& \ln X_{i j}=\beta_{0}+\beta_{1} \operatorname{lnGDP} P_{i}+\beta_{2} \operatorname{lnGDP}_{j}+\beta_{3} \ln P O P_{i}+\beta_{4} \ln P O P_{j}+\beta_{5} \operatorname{lnDist}_{i j}+ \\
& \beta_{6} \text { Border }_{i j}+\beta_{7} E E U(I)+\beta_{8} R T A(\text { both })+\beta_{9} R T A(I I)+u_{i j} \\
& \ln X_{i j}=\beta_{0}+\beta_{1} \ln G D P_{i}+\beta_{2} \ln G D P_{j}+\beta_{3} \ln P O P_{i}+\beta_{4} \ln P O P_{j}+\beta_{5} \operatorname{lnDist}_{i j}+ \\
& \beta_{6} \text { Border }_{i j}+\beta_{7} E E U(I)+\beta_{8} E E U(\text { both })+\beta_{9} E E U(I I)+T_{i j}+u_{i j}
\end{aligned}
$$

Where $\mathrm{X}_{\mathrm{ij}}$ is the exports from country $i$ to country $j$; $\mathrm{GDP}_{\mathrm{i}}$ is the real gross domestic product of country $i$; $\mathrm{GDP}_{\mathrm{j}}$ is the real gross domestic product of country $j$; $\mathrm{POP}_{\mathrm{i}}$ is the population of country $i, \mathrm{POP}_{\mathrm{j}}$ is the population of country $j$; Dist $\mathrm{ij}_{\mathrm{j}}$ is the geographical or economic distance between the two countries, presented as methodology developed by CEPPI ; Border is a dummy variable which takes the value unity if the two countries share a contiguous border and zero otherwise; dummy variables EEU(I), EEU(II) and EEU(both) are identifying if country is a member of EEU or part of Regional trade agreement Eurasian custom union. EEU (I) is a dummy variable which is unity if country $i$ belong to a Eurasian economic union and country $j$ does not and zero otherwise; EEU(II) is a dummy variable which is unity if country $j$ belong to a Eurasian economic union and country $i$ does not and zero otherwise; $\mathrm{EEU}($ both) is a dummy variables that equals 1 if country $i$ and country $j$ are member states of union and zero otherwise is set of control dummy variables included in equation (2) in order to capture all year specific fixed effects.

Control variable EEU(both) is factor standing for trade-creation alongside with the control variable EEU(II) and measured effects of trade in EEU boosted by regional trade agreement inside the union and membership to the EEU, a positive sign of the coefficients will indicate of trade creation in EEU and a positive effect on welfare of member states. Meanwhile variable EEU (I) is measuring level of trade diversion between member states to non-members, this variable was developed and discussed by Endoh (1999) Trade diversions variable with positive sign indicates diversion in trade flows for member states to non-member states.

According to Frankel (1999) GDP is capturing the level of economic development. GDP also captures trade capacities between importer and exporter countries. The coefficients of GDP variables are expected to be positive. 
Population variables stand for the size of the countries and expected to have positive signs. According to Krugman (1991) courtiers with larger population are advantageous in attraction of trade flowsexports compared to smaller countries and having more productive capacity to increase export levels. The variable ( Dist $_{\mathrm{ij}}$ ) is representing economic and geographic distance between paired counties and expected to be negative, since farther counties are the more expansive cost of trade is. Border is dummy variable representing contiguity between county pairs and expanded to be positive since a common border reduces economic and geographic distance and facilities trade by decreasing the cost of it.

Overall all dummy variables are expected to be positive in their signs. This articles mainly focus on welfare effects of EEU, therefore variables EEU (II) and EEU(both) are examined and discussed deeply as policy variables of this model, alongside with EEU(I) with its policy variable capturing level of trade-diversion in EEU. The dataset for this study includes annual date from 2005 to 2016 and captures 5 years before ECU creation until 2010 and 6 years after from 2011 to 2016. Our dataset contains bilateral trade data for 58 countries over a span of 11 years $(2005-2016)$. This selection of countries includes most former republics of the Soviet Union and represents a significant portion of world trade (around 60 percent of it). Bilateral trade is presented as export values from exporter to importer countries. As importer counties members of EEU have been taken and paired to set of exporter counties, therefore there are 5 importer counties paired up with rest 57 export destination counties. In total, there are 285 individual trade relations (5x57) with over 3000 observations in total. Although the sample was not selected entirely randomly, I nevertheless believe that the sample selection provides a fair representation of global trade flows. A full list of countries included in the sample can be found in appendix (1).

The data on exports for the study period 2005-2016 are from Direction of Trade Statistics database (DOTS) by IMF. Data on population and GDP are from World Bank's. Information regarding Distance and geographical parameters are from CEPII database and calculated by CEPII methodology. \{French Centre d'Etudes Prospectives et d'Informations Internationales (CEPII) \}.

\section{EMPIRICAL RESULTS AND DISCUSSIONS}

Models were estimated independently with no fixed effects and with year specific fixed effects respectably. Fixed effect regressions are preferable by most authors studding gravity models of trade and provides relatively unbiased estimates. The models were estimated with annual data for 5 member states of Eurasian economic union for the period 2005 to 2016. That includes Armenia, Belarus, Kazakhstan, Kyrgyzstan and Russia. We analyze the trade flows of these 5 countries to a sample of 58 countries. The list of the countries in the full sample is presented in Appendix (1).

The models were estimated using ordinary least squares (OLS) with robust standard errors regressions. I consider heteroscedasticity, therefore standard errors are generated as robust standard errors to minimize heteroscedasticity effects. The results are reported in Table (1) for both models with and without fixed effects. The results present the variable's behavior is corresponding intuitional predictions, and the estimated coefficients are statistically significant. The Values or $\mathrm{R}^{2}$ is 0.626 and 0.611 for fixed effect and no-fixed effect respectively. The $\mathrm{R}^{2}$ values are corresponding similar models which are valid for cross country analyses and corresponding values from other similar studies applying gravity models of trade in trade flows analyses. Results are discussed for both models, however I believe that fixed effect model has more explanatory power therefore it can be viewed as preferable one.

The coefficients of GDP for both importer and exporter countries are positive in our estimated model and also significant. This supports initial intuitional theory regarding size of countries. The coefficients of Population variables are positive in their signs and significant at 5\% level.

Distance as it was predicted having significant impact of trade flows with is presented by high 
coefficient of 1.403 and negative in its sign, which implies that counties with higher transportation cost as well as other distance related factors are negative for international trade flows.

Table 1: Estimated results (OLS)

\begin{tabular}{lcc}
\hline VARIABLES & Fixed effect year & No fixed effect \\
\hline $\log \left(\mathrm{POP}_{\mathrm{i}}\right)$ & $0.460^{* * *}$ & $0.516^{* * *}$ \\
& $(0.0784)$ & $(0.113)$ \\
$\log \left(\mathrm{POP}_{\mathrm{j}}\right)$ & $0.0763^{* * *}$ & $0.103^{* *}$ \\
& $(0.0188)$ & $(0.0411)$ \\
$\log \left(\mathrm{GDP}_{\mathrm{i}}\right)$ & $0.898^{* * *}$ & $0.949^{* * *}$ \\
& $(0.101)$ & $(0.0819)$ \\
$\log \left(\mathrm{GDP}_{\mathrm{j}}\right)$ & $0.586^{* * *}$ & $0.543 * * *$ \\
& $(0.0121)$ & $(0.0324)$ \\
$\log ($ distance $)$ & $-1.446^{* * *}$ & $-1.403^{* * *}$ \\
& $(0.0355)$ & $(0.0697)$ \\
EEU(I) & $-1.250^{* * *}$ & -0.0530 \\
& $(0.225)$ & $(0.101)$ \\
\hline EEU(II) & $1.133 * *$ & $0.786^{* * *}$ \\
& $(0.370)$ & $(0.238)$ \\
EEU(both) & $0.303 * *$ & $0.354^{* *}$ \\
& $(0.118)$ & $(0.155)$ \\
Contiguous & $1.834 * *$ & $1.869^{* * *}$ \\
& $(0.0490)$ & $(0.131)$ \\
Constant & $-32.07 * * *$ & $-33.37 * * *$ \\
Observations & $(1.349)$ & $(0.794)$ \\
R-squared & 3,420 & 3,420 \\
\hline
\end{tabular}

Robust standard errors in parentheses

$* * * \mathrm{p}<0.01, * * \mathrm{p}<0.05, * \mathrm{p}<0.1$

Border is a significant variable and has a positive sign this supports hypothesis that neighbor counties having improved trade relations, reducing their distance and transportation costs.

The dummy variable, EEU(II) with its estimated coefficient, has the expected positive sign and statistically significant in our model. This variable is expected to measure the degree of trade-creation effects of the regional trade agreement between members. This variable describes effect of Eurasian Economic intra-trade block trade creation and measured by $\left[\operatorname{Exp}\left(\mathrm{B}_{6}\right)-1\right] \times 100 \%$ which is equal to $41 \%$. Variable EEU (II) is positive in its sign and statistically significant with coefficient equal 0.78 it has big impact on trade flow creation, and measured by $\left[\operatorname{Exp}\left(\mathrm{B}_{7}\right)-1\right] \times 100 \%$ equal to 118 percent. The variable alongside with EEU (II) captures effect of trade creation in Eurasian economic union, therefore positive sign in summary of both variables coefficients indicated intra- trade block and net trade creation for EEU member states.

Variable EEU(I) is measuring trade diversion from members to non-members this variable has a negative sign, it's not statistically significant in model with no fixed, however model with year fixed effect underlines significance of the variable. Variable EEU(I) captures level of trade diversion in EEU. Negative sign underlines that EEU is having trade diverting effect; however variable of trade diversion does not explain wealth crating effect of Economic union but underlines trade diversion from other more efficient trade directions.

In the summary, all variable representing trade creation in EEU are significant. Overall impact of trade creation can be presented as following 


$$
\theta E E U(b o t h)+\theta E E U(I I)>0
$$

The summary of coefficients both for EEU(both) and EEU(II) are positive and close to one, therefore we can assume positive impact for intra trade creation and net trade creation for EEU. However, EEU (I) is negative in its value and with high magnitude, therefore control variable of trade-diverting underlines major trade diverting effects of EEU. Trade diverting effects could be partly explained by significantly increased tariff rates applied by Armenia, Kyrgyzstan and high level of export tariffs in general, in this regard export flows were direction from external and more efficient sources to intraunion direction.

\section{SUMMARY AND CONCLUSIONS}

The main purpose of this study was to analyze effect of trade creation and trade diversion of regional trade agreements with the EEU and association to the union. Alongside with policy variables, it can be underlined that other variables, such as country size measured by GDP and population as well as common borders are still playing essential role in trade flows determination.

Estimating gravity model in EEU intra-regional trade flows following conclusions can be made. Firstly, the estimates of gravity model suggest that EEU has been significantly export and import diverted. This in turn demonstrates how international trade flows are driven into the EEU and mitigate other potential trade directions which are mostly explained by common tariff rates implemented in EEU during recent years. On the other hand, EEU also have some positive effects in trade creation of member states in particular intra-block trade has been increased in the union. A positive trend in intrablock trade volume demonstrates that the trade has been diverted in exports and imports from extrablock into-intra block directions. Moreover, CIS region has been always observed as favorable destination for former Soviet Union republics as a reason of shared historical and cultural ties. However, with implication of common tariff rates in the EEU, the trade with former trading partners, but not members of EEU been reduced. Welfare effect of EEU is difficult in the analyses since EEU countries tend to trade with their main trading partner-the Russian Federation and share little trade with other member states. Overall the EEU has the potential in attraction of international trade flows it can be welfare increasing; however, as a newly formed union it has lack of institutional organization and single market.

\section{Funding: This study received no specific financial support.}

Competing Interests: The author declares that s/he has no conflict of interests.

Contributors/Acknowledgement: All the designing and estimation of current research done by sole author

Views and opinions expressed in this study are the views and opinions of the authors, Asian Journal of Empirical Research shall not be responsible or answerable for any loss, damage or liability etc. caused in relation to/arising out of the use of the content.

\section{References}

Aitken, N. D. (1973). The effect of the EEC and EFTA on European trade: a temporal cross-section analysis. The American Economic Review. American Economic Association, 63(5), 881-892. Available at: http://www.jstor.org/stable/1813911.

Anderson, J. E. (2011). The gravity model. Annual Review of Economics, 3(1), 133-160. view at Google scholar

Bergstrand, J. H. (1985). The gravity equation in international trade: some microeconomic foundations and empirical evidence. The Review of Economics and Statistics. The MIT Press, 67(3), 474481. Available at: http://www.jstor.org/stable/1925976.

Carrillo-Tudela, C., \& Li, C. A. (2002). Trade blocks and the gravity model: evidence from latin American countries. Journal of Economic Integration, 667-689. view at Google scholar

Deardorff, T. (1997). International paper follows science in ECF, TCF choice. Pulp and Paper, 71(10), 97-103. view at Google scholar

DeRosa, D. A. (1999). Regional integration arrangements: static economic theory, quantitative 
findings, and policy guidelines. The World Bank. view at Google scholar

Ekanayake, E. M., Mukherjee, A., \& Veeramacheneni, B. (2010). Trade Blocks and the Gravity Model: A Study of Economic Integration among Asian Developing Countries. Journal of Economic Integration, 25(4), 627-643. view at Google scholar

Endoh, M. (1999). Trade creation and trade diversion in the EEC, the LAFTA and the CMEA: 19601994. Applied Economics, 31(2), 207-216. Available at: https://econpapers.repec.org/RePEc:taf:applec:v:31:y:1999:i:2:p:207-216.

Frankel, J. A. (1999). No single currency regime is right for all countries or at all times (No. w7338). National Bureau of Economic Research. view at Google scholar

Frankel, J., Stein, E., \& Wei, S. J. (1995). Trading blocs and the Americas: The natural, the unnatural, and the super-natural. Journal of Development Economics, 47(1), 61-95. view at Google scholar / view at publisher

Helpman, E., \& Krugman, P. R. (1985). Market structure and foreign trade: increasing returns, imperfect competition and the international economy, The MIT Press. view at Google scholar I view at publisher

Koo, W. W., \& Karemera, D. (1991). Determinants of world wheat trade flows and policy analysis. Canadian Journal of Agricultural Economics/Revue canadienne d'agroeconomie. Blackwell Publishing Ltd, 39(3), 439-455. view at Google scholar / view at publisher

Krugman, P. (1980). Paul Krugman. NBER Working Paper Series. view at Google scholar / view at publisher

Krugman, P. (1991). The Move toward Free Trade Zones. Economic Review, 76(6), 5-25. view at Google scholar / view at publisher

Linnemann, H. (1966). An econometric study of international trade flows / Hans Linnemann. NorthHolland Amsterdam. view at Google scholar

Lloyd, P. J., \& Maclaren, D. (2004). Gains and losses from regional trading agreements: a survey. Economic record. Blackwell Publishing Asia Pty Ltd, 80(251), 445-467. view at Google scholar / view at publisher

Pöyhönen, P. (1963). A tentative model for the volume of trade between countries. Weltwirtschaftliches Archiv. Springer, 90, 93-100. Available at: http://www.jstor.org/stable/40436776.

Ravishankar, G., \& Stack, M. M. (2014). The gravity model and trade efficiency: a stochastic frontier analysis of eastern European countries' Potential Trade. The World Economy, 37(5), pp. 690704. view at Google scholar / view at publisher

Robinson, S., \& Thierfelder, K. (2002). Trade liberalization and regional integration: the search for large numbers. The Australian Journal of Agricultural and Resource Economics, 46(4), 585604. view at Google scholar / view at publisher

Russell, M. (2017). Eurasian economic union the rocky road to integration. EPRS Briefing, EPRS Brief, $1-12$ Available at: http://www.europarl.europa.eu/RegData/etudes/BRIE/2017/599432/EPRS_BRI(2017)59943 2 EN.pdf.

Scollay, R., \& Gilbert, J. (2000). Measuring the gains from APEC Trade Liberalisation: An Overview of CGE Assessments. The World Economy, 23(2), 175-197. Available at: https://ideas.repec.org/a/bla/worlde/v23y2000i2p175-197.html.

Tinbergen, J. (1963). Shaping the world economy, the international executive. Wiley Subscription Services, Inc., A Wiley Company, 5(1), 27-30.

Viner, J. (1950). The customs union issue. New York: New York: Carnegie Endowment for International Peace.

Vinokurov, E. (2017). Eurasian economic union: current state and preliminary results. Russian Journal of Economics. Non-profit partnership Voprosy Ekonomiki, 3(1), pp. 54-70. 


\section{Appendix}

Appendix 1: countries included in gravity model

\begin{tabular}{ccc}
\hline Armenia & India & Qatar \\
Argentina & Indonesia & Romania \\
Australia & Iran, I.R. of & Russian Federation \\
Austria & Israel & Singapore \\
Belarus & Italy & South Africa \\
Belgium & Japan & Spain \\
Brazil & Kazakhstan & Sweden \\
Bulgaria & Korea, Republic of & Switzerland \\
Canada & Kyrgyz Republic & Thailand \\
Chile & Lebanon & Turkey \\
China,P.R.: Mainland & Malaysia & Turkmenistan \\
Colombia & Mexico & Ukraine \\
Czech Republic & Mongolia & United Arab Emirates \\
Denmark & Morocco & United Kingdom \\
Egypt & Netherlands & United States \\
France & Nigeria & Uruguay \\
Georgia & Norway & Uzbekistan \\
Germany & Pakistan & Vietnam \\
Greece & Poland & \\
Hungary & Portugal & \\
\hline
\end{tabular}

